\title{
Sequence Analysis of the Chalcone Synthase Gene Intron in Four Petunia Jussieu Taxa
}

\author{
R.J. Griesbach and R.M. Beck \\ Floral and Nursery Plants Research, U.S. National Arboretum, U.S. Department of Agriculture, \\ Agricultural Research Service, Beltsville, MD 20705-2350
}

\begin{abstract}
Additional IndeX words. Petunia integrifolia, Petunia littoralis, Petunia altiplana, molecular markers, taxonomy
Abstract. The sequence of the intron within the chalcone synthase A gene $(\boldsymbol{C h s A})$ was used to characterize Petunia integrifolia subsp. integrifolia var. depauperata (Fries) Smith et Downs, P. altiplana Ando et Hashimoto, $P$. littoralis Smith et Downs, and an unknown taxon from the town of Torres in Brazil. Based upon the intron, the Torres taxon most closely resembled $\boldsymbol{P}$. integrifolia. The unrooted phylogenetic tree suggested that $\boldsymbol{P}$. integrifolia was more closely related to $P$. littoralis than $P$. altiplana.
\end{abstract}

Fries (1911) divided Petunia into two subgenera (Pseudonicotiana and Eupetunia) and recognized three distinct Eupetunia species (Petunia violacea Lindley, P. inflata Fries, and P. occidentalis Fries). Petunia violacea had the largest flowers and pendant pedicels, while $P$. occidentalis had the smallest flowers and erect pedicels. Petunia inflata was intermediate between $P$. violacea and $P$. occidentalis with large flowers and erect pedicels. In addition, Fries recognized a diminutive subspecies of $P$. violacea $(P$. violacea subsp. depauperata) with very small flowers and leaves.

Because of nomenclatural priority, Schinz and Thellung (1915) changed the name of $P$. violacea to $P$. integrifolia (Hooker) Schinz et Thellung. The name P. integrifolia predated the name P. violacea. This taxon was first described by Hooker (1831) as Salpiglossis integrifolia and renamed P. violacea by Lindley (1833).

Petunia integrifolia and P. inflata were considered by Smith and Downs (1966) to be synonymous [P. integrifolia var. integrifolia (Fries) Smith et Downs]. Smith and Downs also considered $P$. violacea subsp. depauperata and P.occidentalis to be synonymous [P. integrifolia var. depauperata (Fries) Smith et Downs].

Several additional Eupetunia taxa have subsequently been recognized as distinct species: P. altiplana Ando and Hashimoto (1993), P. bajeensis Ando and Hashimoto (1998), P. bonjardinensis Ando and Hashimoto (1993), P. guarapuavensis Ando and Hashimoto (1995), P. interior Ando and Hashimoto (1996), P. littoralis Smith and Downs (1964), P. mantiqueirensis Ando and Hashimoto (1994), P. occidentalis Tsukamoto et al. (1998), $P$. reitzii Smith and Downs (1964), P. riograndensis Ando and Hashimoto (1998), P. saxicola Smith and Downs (1964), and $P$. scheideana Smith and Downs (1964).

H.J.W. Wijsman (personal communication) reported that the traits used to distinguish many of the $P$. integrifolia taxa were correlated with geographical distribution, concluding that various taxa were subspecies of a single broadly defined species. He recognized three different subspecies $[P$. integrifolia subsp. integrifolia (Fries) Wijsman, $P$. integrifolia subsp. inflata (Fries) Wijsman, and $P$. integrifolia subsp. occidentalis (Fries) Wijs$\mathrm{man}]$ and a single variety $[P$. integrifolia subsp. integrifolia var.

Received for publication 27 July 2004. Accepted for publication 9 Sept. 2004 Mention of trade names or commercial products is solely for the purpose of providing specific information and does not imply recommendation or endorsement by the U.S. Dept. of Agriculture. depauperata (Fries) Wijsman]. A similar study was conducted by Ando et al. (1995) and concluded that all the species, except $P$. littoralis, were clearly distinct. Petunia littoralis could not be distinguished from $P$. integrifolia subsp. integrifolia var. depauperata. In addition, all of the P. integrifolia subspecies in their native habitats were separately distributed and readily distinguished from one another.

Additional taxonomic confusion resulted from the spontaneous appearance in botanical gardens of a purple-flowered intraspecific hybrid between P. axillaris and P. integrifolia (Loudon, 1840). All of these garden hybrids were called $P$. violacea. Vilmorin (1863) tried unsuccessfully to correct the problem in nomenclature by naming the intraspecific hybrid $P$. $\times$ hybrida. By 1900 , the true species had disappeared from cultivation and even one of the herbarium specimens of $P$. integrifolia in the Lindley Herbarium at the Royal Botanic Garden at Kew was reported to be a P. axillaris X P. integrifolia hybrid (Ferguson and Ottley, 1932).

In an effort to help solve the species identification problem, several molecular marker studies were conducted using speciesspecific repeated DNA (Shepherd et al., 1990), rDNA (Benabdelmouna and Abirached-Darmency, 1997; Kabbaj et al., 1995; Zeboudj et al., 1994), randomly amplified DNA(Benabdelmouna et al., 1999; Cerny et al., 1996), or the chalcone synthase intron (Griesbach et al., 2000). However, the taxa that were actually used in many of these studies are uncertain. For example, phylogenetic analysis using rDNA suggested that two taxa called " $P$. integrifolia" and " $P$. violacea" were distantly related (Kabbaj et al., 1995), but those names refer to the same taxon. Furthermore, the complex taxonomy of Petunia has caused many cultivated species to be misidentified.

The coding sequence of the chalcone synthase gene (Chs) is highly conserved among plants and has been used to define taxonomic relationships (Niesbach-Klösgen et al., 1987; Rauscher et al., 1999). There is a $>66 \%$ DNA sequence similarity between monocots and dicots. Chs was used to study the phylogenetic relationships between seven different ecotypes of Ipomoea purpurea (Durbin et al., 2001). Within the coding sequence of the ecotypes, there were only 23 nucleotide substitutions out of 1104 base pairs (bp); while within the intron sequence of the ecotypes, there was significant variation in the number and type of transposable element insertions. Other studies have also shown that transposable elements can be integral parts of introns (Casacuberta and Santiago, 2003; Feschotte et al., 2002). 
We have previously used the molecular heterogeneity in the ChsA intron to characterize $P$. integrifolia subsp. integrifolia var. depauperata, P. altiplana, and P. xhybrida by comparing the Rsa1 restriction digest profile of several accessions of each species (Griesbach et al., 2000). This study extends that research by comparing the DNA sequence of the $C h s A$ intron from several closely related taxa. The sequence data were then used to help in the identification of a unique Petunia taxon (Petunia sp. Torres) that we have used extensively in breeding to create drought-tolerant germplasm (Griesbach et al., 2002). It is important that a species name be associated with this taxon.

\section{Material and Methods}

Plant material. Four Petunia taxa were collected from the wild [Fig. 1; P. integrifolia subsp. integrifolia var. depauperata (Pi; lat. $29^{\circ} 15^{\prime} 51^{\prime \prime} \mathrm{S}$, long. $\left.49^{\circ} 41^{\prime} 33^{\prime \prime} \mathrm{W}\right)$, P. altiplana (Pa; lat.

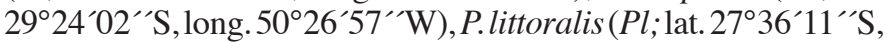
long. $\left.48^{\circ} 26^{\prime} 09^{\prime \prime} \mathrm{W}\right)$ and Petunia sp. Torres ( $P T$; lat. $29^{\circ} 21^{\prime} 26^{\prime \prime} \mathrm{S}$, long. $\left.49^{\circ} 44^{\prime} 06^{\prime \prime} \mathrm{W}\right)$ ]. These plants were identified based upon the taxonomic key developed by Ando and Hashimoto (Fig. 2). The collected plants contained seed capsules that were used to raise populations. The plants within each of the populations were analyzed. Five randomly selected seedlings were used to obtain the morphological data and three randomly selected seedlings were used to obtain the DNA sequence data.

Plants were grown in a mixture of 50\% perlite and peat under standard greenhouse conditions and fertilized weekly with a solution of $20 \mathrm{~N}-8.7 \mathrm{P}-16.6 \mathrm{~K}$ fertilizer at $200 \mathrm{mg} \cdot \mathrm{L}^{-1}$ nitrogen. Leaf measurements were made on mature, fully expanded leaves before flowering.

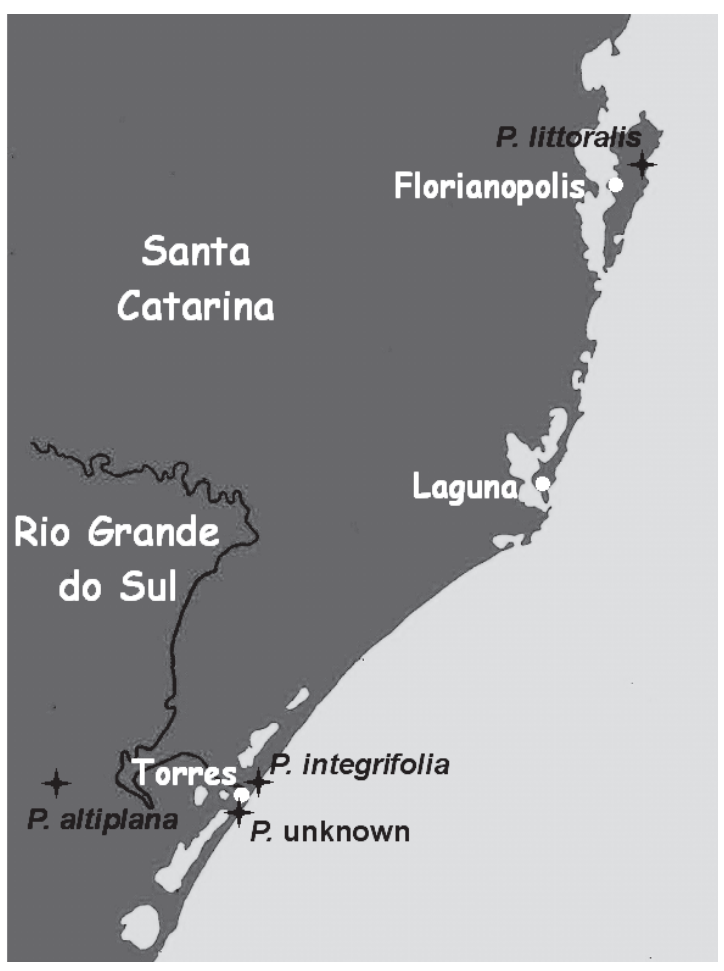

Fig. 1. Location of Petunia integrifolia ssp. depauperata, $P$. littoralis, $P$. altiplana, and the taxon from Torres within Brazil.
DNA ISOlation AND AMPLification. Genomic DNA was isolated from either leaves or flowers using DNeasy Plant Mini Kit (Qiagen, Valencia, Calif.) and further purified with anion-exchange resin using the Genomic-tip Protocol of Qiagen's Blood and Cell Culture DNA Kit. Purified DNA was precipitated with 50\% isopropanol (v/v), washed with $70 \%$ ethanol, and resuspended in 30 to $50 \mu \mathrm{L}$ water.

We previously developed a polymerase chain reaction (PCR) system for amplifying the ChsA intron in several Petunia taxa (Griesbach et al., 2000). PCR primers for amplifying the chalcone synthase (Chs) intron were designed by hand from the reported sequences of eight (Niesbach-Klosgen et al., 1987). Primers were designed to include a highly conserved region of the coding sequence as an internal control for checking the accuracy of amplification. The two primers were initially designed to be complementary to 20 nucleotides before the intron (5'-GAACAGCCACACCTACAAAC-3') and to 20 nucleotides after the intron (5'-AACCCTGCTGGTACATCATG-3').

Using these two primers it was possible to amplify the intron, but we could not completely sequence the product directly from the PCR product. Therefore, internal primers based upon the DNA sequence of $P i$ were designed for the entire length of the intron. The forward primers were 5'-TGTTGCACGTCTCCAATAGC-3', 5'-ATGGAAGGTAGAAAGAGGG-3', 5' -GAAAGAGAAACTGACGTGAAAG-3', 5'-GATGCTAGGCAAGACATAGTGG3', and 5'-CGAAAATTCGTGTGTTTCTAGC-3'. The reverse primers were 5'-CCACTATGTCTTGCCTAGCATC-3', 5'-CTTTCACGTCAGTTTCTCTTTC-3', 5'-CCCTCTTTCTACCTTCCAT-3', 5'-GCTATTGGAGACGTGCAACA-3', and $5^{\prime}$-GCTAGAAACACACGAATTTTCG-3'. These internal primers were used in various combinations to amplify partial sequences.

A Perkin-Elmer DNA Thermal Cycler (Perkin-Elmer, Norwalk, Conn.) was used to amplify the intron. The reaction mix contained $10 \mu \mathrm{L}\left(1 \mathrm{mg} \cdot \mathrm{mL}^{-1}\right)$ genomic DNA, $1.5 \mu \mathrm{L}$ AmpiTaq Gold Taq DNA polymerase (PE Applied Biosystems, San Jose, Calif.), $10 \mu \mathrm{LGeneAmp} \mathrm{MgCl}_{2}$-free 10X PCR Buffer(PEApplied Biosystems), $8 \mu \mathrm{L}$ mixed dNTPs (10 mM), $15-20 \mu \mathrm{L} \mathrm{MgCl}_{2}(10$ $\mathrm{mm}), 10 \mu \mathrm{L}$ mixed primers (20 mM), and water to a total volume of $100 \mu \mathrm{L}$. An overlay of $20 \mu \mathrm{L}$ mineral oil was used in each reaction tube.

The PCR cycle began with a Taq polymerase heat activation step of $95^{\circ} \mathrm{C}$ for $12 \mathrm{~min}$. This was followed by $92^{\circ} \mathrm{C}$ for $2 \mathrm{~min}$, 40 cycles of $92^{\circ} \mathrm{C}$ for $30 \mathrm{~s}, 60^{\circ} \mathrm{C}$ for $2 \mathrm{~min}$, and $72^{\circ} \mathrm{C}$ for $1 \mathrm{~min}$, and $72{ }^{\circ} \mathrm{C}$ for $10 \mathrm{~min}$.

\section{Pedicel deflexed in fruiting stage}

2. Stigma between anthers of longest stamen and shortest stamen

\section{Main stem prostrate}

4. Leaves prostrate, broad spatulate, subglabrous; stem hirsute, branched at lower unflowered internodes ------------------------------ P. altiplana

4. Leaves erect, linear to oblong; stem unbranched at lower unflowered internodes
5. Stem and leaves glabrous P. littoralis
5. Stem and leaves hirsute------------------ P. integrifolia

Fig. 2. Taxonomic key for the identification of Petunia altiplana, P. littoralis, and P. integrifolia ssp. integrifolia var. depauperata (modified from Ando and Hasimoto, 1993, 1994, 1995, and 1996; Smith and Downs, 1966). 
Cloning and Sequencing. PCR products were cloned into plasmid DNA using the pGem-TEasy Vector System II (Promega, Madison, Wis.) according to the manufacturer's protocol (Promega, 2004). Individual white-colored (clones carrying inserts) bacterial colonies were harvested and transferred into 15-mLFalcon snap-top tubes containing $3 \mathrm{mLLB}$ medium supplemented with amplicillin (final concentration of $100 \mu \mathrm{g} \cdot \mathrm{mL}^{-1}$ ). The cultures were shaken (225 rpm) at $37^{\circ} \mathrm{C}$ for 16 to $18 \mathrm{~h}$. Plasmid DNA was isolated from the bacteria using the RPM Kit (Bio 101, Carlsbad, Calif.) according to the manufacturer's protocol (Qbiogene, 2004).

Purified plasmid DNA containing cloned PCR products were cycle sequenced on an ABI Prism 310 Genetic Analyzer using the ABI Prism Big Dye Terminator Cycle Sequencing Ready Reaction Kit (PE Applied Biosystems) in a GeneAmp 2400 PCR System (Perkin-Elmer) using the manufacturer's protocol (Applied Biosystems, 2004).

DNA ANALYSIS. The intron sequences were aligned by the Clustal method (Higgins and Sharp, 1988) as implemented in the DAMBE software (Xia and Xie, 2001). Repeated sequences were identified using REPuter software (Kurtz and Schleiermacher, 1999). The motif alignment and search tool (MAST) was used to identify motifs within the intron (Bailey and Gribskov, 1998). The E-value of a sequence is the expected number of sequences in a random database of the same size that would match the motif as well as the test sequence does.

Distance analysis was carried out using the PHYLIP software (Felsenstein, 2004). The Kimura two-parameter method (DNADIST program in PHYLIP) was used to calculate pair wise nucleotide divergence values (Kimura, 1980). For each data set, an unrooted neighbor-joining dendrogram was constructed from the distance matrix using the NEIGHBOR program in PHYLIP. Bootstrap values were calculated for 1000 replicates.

\section{Results and Discussion}

The most recent taxonomic key (Ando et al., 1995) places $P$. integrifolia subsp. integrifolia var. depauperata $(P i)$, P. altiplana $(P a)$, and $P$. littoralis $(P l)$ in the same grouping based upon floral structure. They are distinguished from each other by leaf morphology (Fig. 2). Based upon leaf shape, the taxon from Torres most closely resembles $P l$ with glabrous and succulent leaves (Table 1 ). However, $P l$ and the taxon from Torres are found in similar dry costal habitats and could have independently evolved glabrous and succulent leaves (convergent evolution). Leaf morphology may not accurately represent the true taxonomic relationship of three species. DNA markers may be a more accurate means of defining the taxonomic relationships between these species.

In Petunia $\times$ hybrida 'V30', there are eight complete copies of the chalcone synthase gene; however, only two (ChsA and ChsJ) are expressed during normal plant development (Koes et al., 1989a). ChsA and ChsJ contain introns that differ in size and are highly divergent in sequence. About $90 \%$ of the total Chs mRNA pool is transcribed from ChsA (Koes et al., 1989b). The primers used in this study amplify a single PCR product that was specific expressed within floral tissue (data not shown). Therefore, the PCR product corresponds to $C h s A$.

The PCR products from $P i, P a, P l$, and $P T$ were cloned and sequenced. At least three different plants within the individual populations of the species were analyzed. In each instance, there was no difference in the DNA sequence of the ChsA intron between plants within a population.
The intron in $P i$ was 1275 bp with two different repeated segments of 29 and 38 bp (Figs. 3 and 4). The intron in $P T$ was identical to that in $P i$. In contrast, the $P l$ intron differed from that of $P i$ with six nucleotide substitutions, two insertions of 1 and $2 \mathrm{bp}$ each, and 1 deletion of $1 \mathrm{bp}$. Five of the substitutions were transversions and one was a transition.

The $P a$ intron was very different from $P i$ with 21 base substitutions, 11 of which were transversions. Besides the substitutions, $P a$ had three insertions of 1,2 , and $349 \mathrm{bp}$ each and three deletions of 1,1 , and $133 \mathrm{bp}$ each. The $349 \mathrm{bp}$ insertion was within the 133 bp deletion. It is likely that a single event led to deletion/insertion in $P a$. A DNA substitution of unequal length would result in a deletion/insertion event. Most of the $349 \mathrm{bp}$ insertion was also present in $P$. $\times$ hybrida ( $P h$; Fig. 5). The first 33 bp did not match very closely with only $30 \%$ homology; however, the remainder of the sequence was highly homologous. The insertion in $\mathrm{Ph}$ differed from the $P a$ insertion by having four substitutions and three insertions of 1, 2, and 3 bp relative to $P a$ (Fig. 5).

The 29 and 38 bp repeat sequences found in $P a, P i$, and $P l$ are also in $P h$, but not repeated (Fig. 4). Within the 29 bp sequence, $P h$ differed from $P i$ in one substitution and one $1 \mathrm{bp}$ insertion. There were four substitutions and one $2 \mathrm{bp}$ insertion within the 38 bp sequence from $P h$.

A single motif (TATCACAATTGACTCTTCATT) with an E $=7.4 \mathrm{e}^{-06}$ was identified within both repeated sequences starting at positions $40,175,210$, and 240 . This suggests that these two different repeated sequences may have a common origin. This motif did not correspond to any known transposable element or repeated sequence.

Neither repeated sequences were flanked by an inverted repeat, preventing them from being classified as a miniature inverted repeat (MITE; Feschotte at al., 2002). In addition, they were too short to be considered a short interspersed element (SINE; Feschotte at al., 2002). A potential MITE was found starting at position 44, where an inverted repeat (TTAATTGACTCTT) was found flanking a $356 \mathrm{bp}$ sequence. Although the flanking invert repeat and the 356 bp sequence did not correspond to any known MITE family, it is still possible that this sequence is a MITE. MITEs have only recently been discovered and new families are still being identified.

In all three species, the intron contained one open reading frame with a TATA box (position 359) and transcription start signal (position 371) as described by Joshi (1987). However, the translation product did not correspond to any known protein.

Based upon the ChsA intron, the Torres taxon most closely resembled $P i$. The intron sequences of the two taxa were identical. The unrooted gene tree suggests that $P i$ is more closely related to $P l$ than $P a$ (Fig. 6). The gene trees based upon parsimony and maximum likelihood methods had the same topology (data not

Table 1. Leaf morphology of Petunia integrifolia ssp. depauperata, $P$. littoralis, P. altiplana, and the taxon from Torres. Differences between the means within each column that are followed by the same letter are nonsignificant (Tukey's HSD test).

\begin{tabular}{lcccc}
\hline & \multicolumn{4}{c}{ Leaf traits } \\
\cline { 2 - 5 } Taxon & $\begin{array}{c}\text { Width/length } \\
(\mathrm{cm})\end{array}$ & $\begin{array}{c}\text { Length } \\
(\mathrm{cm})\end{array}$ & $\begin{array}{c}\text { Trichomes } \\
\left(\text { no. } / \mathrm{cm}^{2}\right)\end{array}$ & $\begin{array}{c}\text { Thickness } \\
(\mu \mathrm{m})\end{array}$ \\
\hline P. integrifolia & $2.3 \mathrm{a}$ & $3.5 \mathrm{a}$ & $21.0 \mathrm{a}$ & $459 \mathrm{a}$ \\
$P$. littoralis & $3.2 \mathrm{~b}$ & $4.1 \mathrm{~b}$ & $3.0 \mathrm{~b}$ & $728 \mathrm{~b}$ \\
P. altiplana & $1.3 \mathrm{c}$ & $7.1 \mathrm{a}$ & $6.0 \mathrm{a}$ & $478 \mathrm{ba}$ \\
Torres & $1.5 \mathrm{~d}$ & $2.6 \mathrm{~b}$ & $0 \mathrm{c}$ & $879 \mathrm{c}$ \\
\hline
\end{tabular}




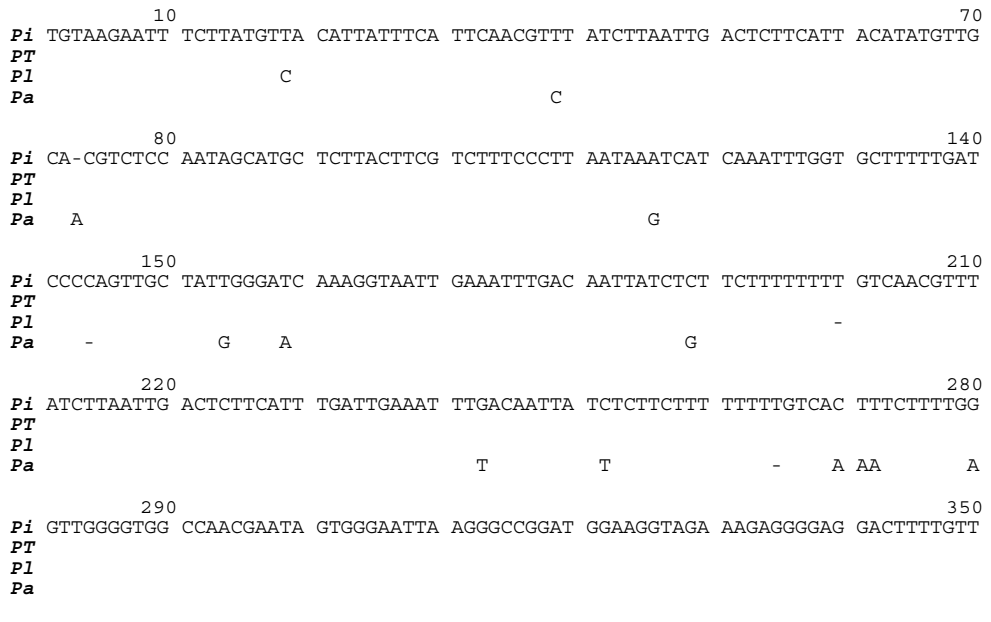

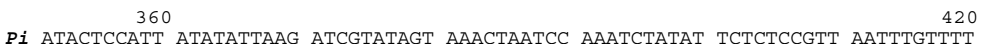
$P i$
$P T$
$P 1$ $\begin{array}{lll}P 1 & T & \text { T } \\ P a & \end{array}$
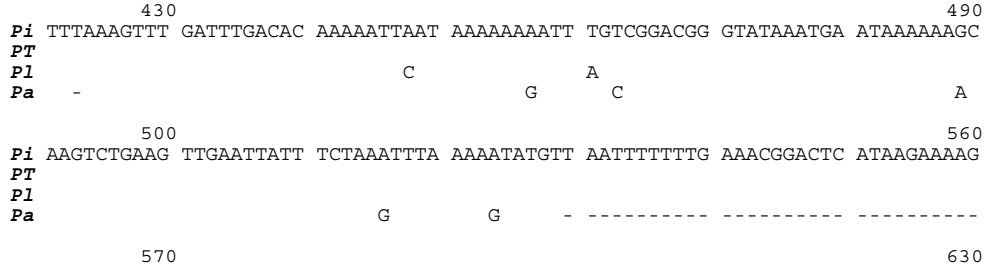

$P$ i TATAACAACA TAgTAGGACG GCGGGGGTA TTGTTACTAG TACTT-....

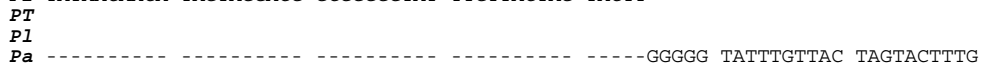

$640 \quad 700$

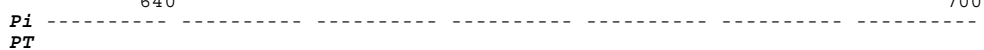

$P 1$

a gaAatagagc tagcGaAatT tCAagattTC tGtcGaAaAt tCGtgtgttt Ctagctagta CtTGatgtta
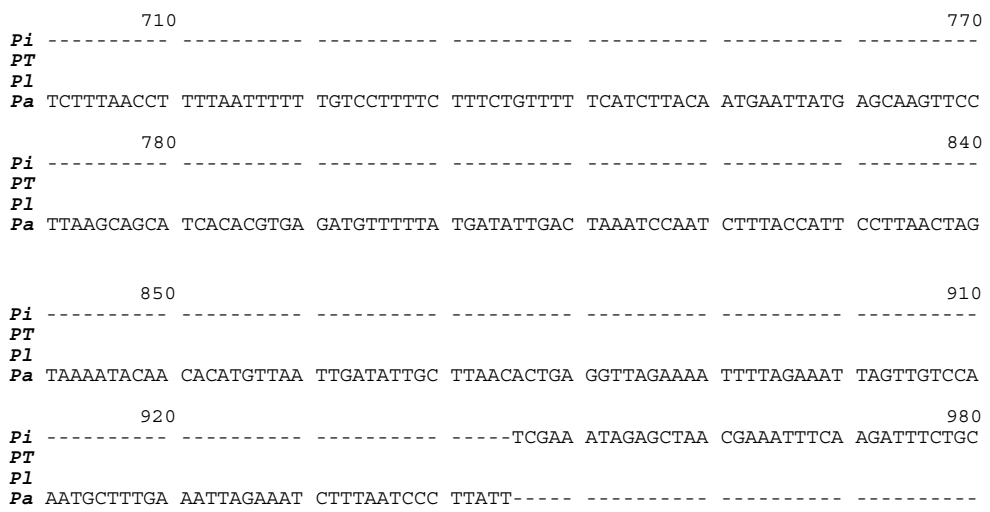

$990 \quad 1050$

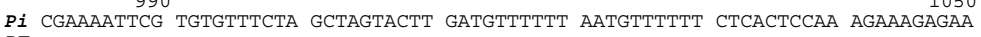
PT

$P A$ 1060
$P i$ ACTGACGTGA AAGCTCAAAA GATCATGAAT CTTACTAACT TTGTGGAACT AAATA--GTA CATCAGAATG $\begin{array}{lll}P a & \mathrm{~A} & \mathrm{CA} \\ & & \end{array}$ 1030
Pi TTTCTGACAT GTGAAAA-TG AAAGCTCGTA ATTTTCTTCT TTTATTTATT GAGGGGTTTT T--GCATGCT $\begin{array}{llll}P 1 & \\ P T & \text { A } & \text { T } & \text { T } \\ P a & & \text { G } & \text { T }\end{array}$

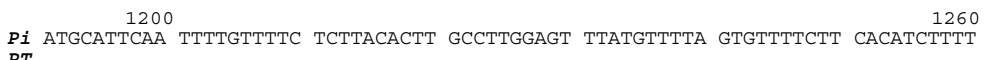

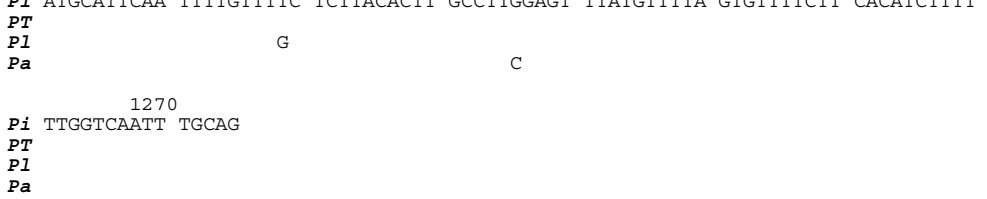

shown). The genetic distance between $P l$ and $P i$ was 0.0116, as compared with 0.0275 for $P i$ and $P a$.

The Chs phylogeny supports the conventional classification of these three species, in that $P l$ and $P i$ are more closely related than $P i$ and $P a$ (Fig. 2). $P$ etunia altiplana was separated from $P i$ and $P l$ based upon its distinct growth habit and flower structure (Ando and Hashimoto, 1993). Unlike $P i$ and $P l, P a$ forms stems with short internodes, lateral branches, and adventitious roots. $P a$ produces flowers with a lighter corolla tube than limb, whereas $P l$ and $P i$ produce flowers with a darker tube than limb. $P e$ tunia littoralis was separated from $P i$ based upon its glabrous stems and lanceolate succulent leaves (Smith and Downs, 1966). A principal component analysis of 33 different morphological traits showed that $P l$ and $P i$ formed a distinct cluster separated from $P$. integrifolia subsp. integrifolia var. integrifolia (Ando et al., 1995b). However, neither leaf shape nor stem trichome density were included in the traits studied.

Our study suggests that the chalcone synthase intron would be a good candidate for determining the taxonomic relationship of closely related taxa. There are many types of gene mutations (single base pair insertions, deletions, and substitutions; and multiple base pair insertions, deletions, and rearrangements) that occur naturally (Gustafsson and Ekberg, 1977). If a DNA coding sequence is used to study evolutionary relationships, then many of these types of mutations would not be screened because they lead to nonfunctional gene products and are potentially lethal. One of the most common mutations is ultraviolet light-induced deletions at TT sites (Drake, 1970).

In order to study the phylogenetic relationships of closely related species, one should analyze noncoding sequences that have accumulated a wide array of mutations. The difficulty is in finding a highly variable homeologous sequence in multiple species. If this sequence is an intron in a highly conserved gene, then it can be easily found, PCR amplified, and sequenced. Besides chalcone synthase, histones, tubulin, and actins are conserved genes with introns (Doyle at al., 1996; Drouin and Dover, 1990; Wu et al., 2003).

When using conserved genes, one needs to make sure that a pseudogene is not being analyzed. Many conserved genes like $C h s$ exist as a gene family with several members of the family being nonfunctional paralogous loci (i.e., pseudogenes). In a study of the internal transcribed spacer region (ITS) of Quercus, several independent reports disagreed as to the phylogenetic trees generated from supposedly the same ITS sequence. The difference in the results was found

Fig. 3 (left). The DNA sequence of the intron from the chalcone synthase A gene (ChsA) in Petunia integrifolia ssp. integrifolia var. depauperata $(P i)$, Petunia sp. from Torres $(P T)$, P. littoralis $(P l)$, and $P$. altiplana $(P a)$. Only differences from the $P i$ sequence are shown; “-” represents nucleotides not present in a particular species. 


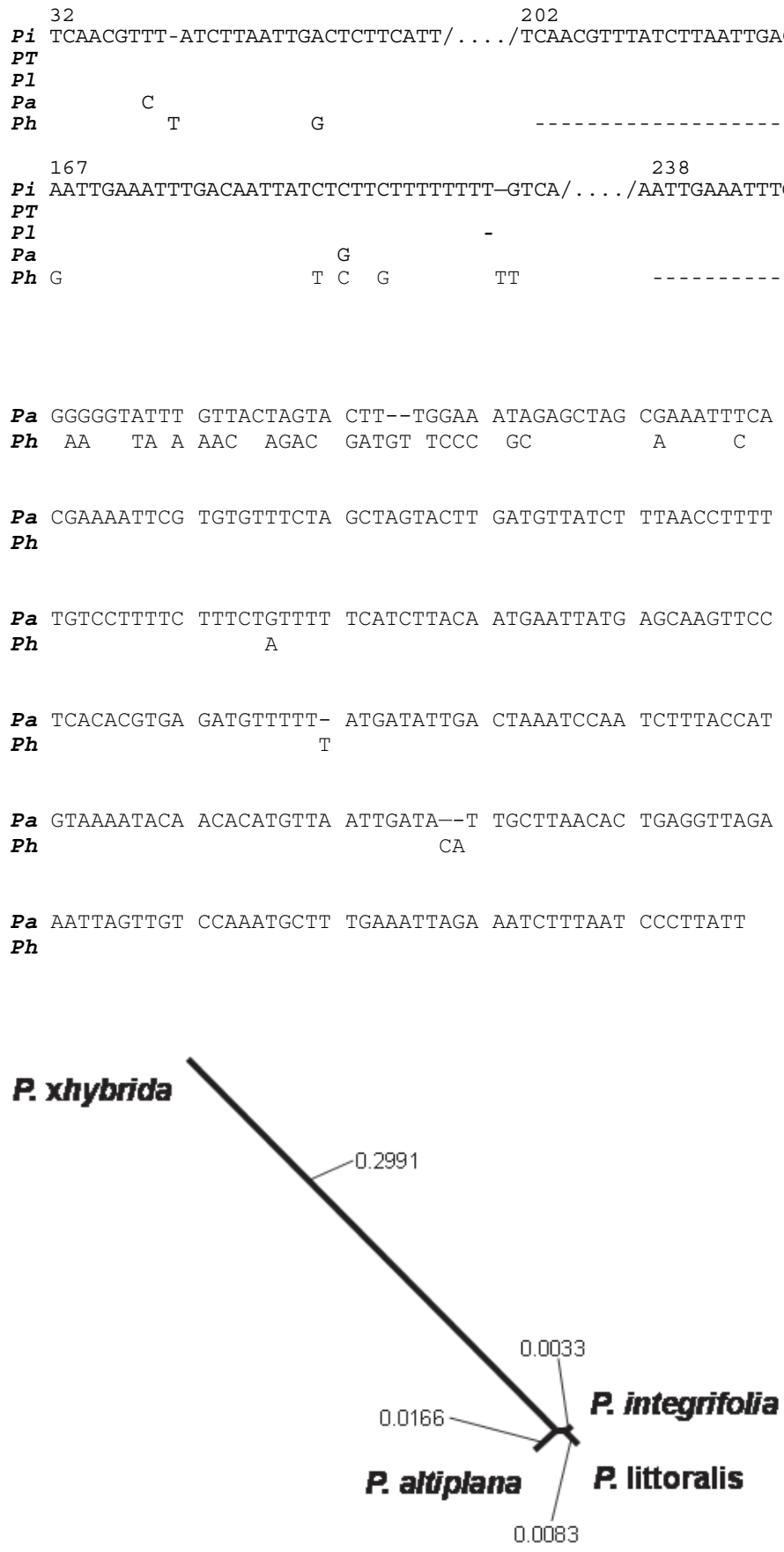

Fig. 6. An unrooted neighbor-joining dendrogram of Petunia constructed from the distance matrix of branch lengths using the NEIGHBOR program in PHYLIP (Felsenstein, 2004).

to be due to analysis of pseudogenes (Mayol and Rossello, 2001). One way to prevent the analysis of introns from pseudogenes is to compare the conserved coding sequences flanking the intron. In our study, we included 200 nucleotides of the 3' flanking coding sequence in the initial PCR amplification product.

This study demonstrates that sequence heterogeneity of introns may be useful in elucidating the evolutionary relationships between species. By comparing different gene trees, it should be possible to establish an accurate evolutionary tree of a genus. Further studies of additional introns with appropriate outgroups included could be used to develop an evolutionary tree of the Petunia.
Fig. 4. A comparison of the two different repeated sequences in Petunia integrifolia ssp. integrifolia var. depauperata $(P i)$, Petunia sp. from Torres $(P T), P$. littoralis $(P l), P$. altiplana $(P a)$, and $P$. xhybrida 'V30' $(P h)$. The $P h$ sequence was reported in Koes et al. (1989). Only differences from the $P i$ sequence are shown; "-" represents nucleotides not present in a particular species.
Fig. 5. The sequence of the $177 \mathrm{bp}$ insertion found in Petunia altiplana $(P i)$ and $P$. $\times$ hybrida 'V30' $(P h)$. The $P h$ sequence was reported in Koes et al. (1989). Only differences from the $P i$ sequence are shown; "-" represents nucleotides not present in a particular species.
Ando, T. and G. Hashimoto. 1993. Two new species of Petunia (Solanaceae) from southern Brazil. Bot. J. Linnean Soc. 111:265-280.

Ando, T. and G. Hashimoto. 1994. A new Brazilian species of Petunia (Solanaceae) from the Sierra da Mantiqueira. Brittonia 46:340-343.

Ando, T. and G. Hashimoto. 1995. Petunia guarapuavensis (Solanaceae): A new species from planalto of Paraná and Santa Catarina, Brazil. Brittonia 47:328-334.

Ando, T. and G. Hashimoto. 1996. A new Brazilian species of Petunia (Solanaceae) from interior Santa Catarina and Rio do Sul, Brazil. Brittonia 48:217-223.

Ando, T. and G. Hashimoto. 1998. Two new species of Petunia (Solanaceae) from southern Rio Grande do Sul, Brazil. Brittonia 50:483-492.

Ando, T., M. Kurata, S. Sasaki, G. Hashimoto, and E. Marchesi. 1995b. Comparative morphological studies on infraspecific taxa of Petunia integrifolia. J. Jpn. Bot. 70:205-217.

Ando, T., M. Masahiro, S. Sasaki, Y. Ueda, G. Hasimoto, and E. Marchesi. 1995. Comparative morphological studies in infraspecific taxa of Petunia integrifolia (Hook.) Schinz et Thell. J. Jpn. Bot. 70:205-217.

Applied Biosystems. 2004. Product and service literature. 9 Sept. 2004. $<$ http://docs.appliedbiosystems.com/search.taf?_UserReference=0319 10BF4931B31341407C6E >.

Bailey, T.L. and M. Gribskov. 1998. Combining evidence using pvalues: Application to sequence homology searches. Bioinformatics 14:48-54.

Benabdelmouna,A. and M. Abirached-Darmency. 1997. Distribution and chromosomal organization of 18S-5.8S-25S and 5S rDNA in Petunia species. Agronomie 97:349-360.

Benabdelmouna,A., D. Peltier, C. Humbert, and M.Abirached-Darmency. 1999. Southern hybridization and fluorescent in situ hybridization detect 
three RAPD-generated PCR products useful as introgression markers in Petunia. Theor. Appl. Genet. 98:10-17.

Casacuberta J.M. and N. Santiago. 2003. Plant LTR-retrotransponsons and MITEs: Control of transposition and impact on the evolution of plant genes and genomes. Gene 311:1-11.

Cerny, T.A., C. Caetano-Anollés, R. Trigiano, and T.W. Starman. 1996. Molecular phylogeny and DNA amplification fingerprinting of Petunia taxa. Theor. Appl. Genet. 92:1009-1016.

Doyle, J.J., V. Kanazin, and R.C. Shoemaker. 1996. Phylogenetic utility of histone $\mathrm{H} 3$ intron sequences in the perennial relatives of soybean. Mol. Phylogenet. Evol. 6:438-447.

Drake, J. 1970. Molecular basis of mutation. Holden-Day, San Francisco.

Drouin, G. and G.A. Dover.1990. Independent gene evolution in the potato actin gene family demonstrated by phylogenetic procedures for resolving gene conversions and the phylogeny of angiosperm actin genes. J. Mol. Evol. 31:132-150.

Durbin, M.L., A.L. Denton, and M.T. Clegg. 2001. Dynamics of mobile element activity in chalcone synthase loci in the common morning glory (Ipomoea purpurea). Proc. Natl. Acad. Sci. USA 98:5084-5089.

Felsenstein, J. 2004. Inferring phylogenies. Sinauer Assoc., Sunderland, Mass.

Feschotte, C., N. Jiang, and S.R. Wesler. 2002. Plant transposable elements: where genetics meets genomics. Nature Rev. (Genetics) 3:329-341.

Fries, R.E. 1911. Die Arten der Gattung Petunia. Kungl. Svenska Vetenskapsakademiens Handlingar. 46:1-72.

Ferguson, M.C. and A.M. Ottley. 1932. Studies on Petunia III. A redescription and additional discussion of certain species of Petunia. Amer. J. Bot. 19:385-407.

Griesbach, R.J., R.M. Beck, and J.R. Stehmann. 2000. Molecular heterogeneity of the chalcone synthase intron in Petunia. HortScience $35: 1347-1349$.

Griesbach, R.J., J.W. Neal, and J. Bentz. 2002. Arthropod resistance in a Petunia ecotype with glabrous leaves. HortScience 37:383-385.

Gustafsson, A. and I. Ekberg. 1977. Types of mutations. In: Manual on mutation breeding. Internal Atomic Energy Agency, Tech. Rpt. 199:107-113.

Higgins, D.G. and P.M. Sharp. 1988. Clustal: A package for performing multiple sequence alignments. Gene Dev. 3:237-244.

Hooker, W.J. 1831. Salpiglossis integrifolia. Curtis's Bot. Mag. 58:3113.

Joshi, C.P. 1987. An inspection of the domain between putative TATA box and translation start site in 79 plant genes. Nucl. Acid Res. 15:6643-6653.

Kabbaj,A., F.Zeboudj, D. Peltier,A. Tagmount, M. Tersac,H. Dulieu, and A. Berville. 1995. Variation and phylogeny of the ribosomal DNA unit types and 5 S DNA in Petunia. Genet. Res. Crop Evol. 42:311-325.

Kimura, M. 1980. A simple method for estimating evolutionary rate of base substitution through comparative studies in nucleotide sequences. J. Mol. Evol. 16:111-120.

Koes, R.E., C.E. Spelt, P.J. van Elzen, and J.N. Mol. 1989a. Cloning and molecular characterization of the chalcone synthase multigene family of Petunia hybrida. Gene 81:245-257.

Koes, R.E., C.E. Spelt, and J.N. Mol. 1989b. The chalcone synthase multigene family of Petunia hybrida (V30): Differential, light-regulated expression during flower development and UV light induction. Plant Mol. Biol. 12:213-225.

Kurtz, S. and C. Schleiermacher. 1999. REPuter: Fast computation of maximal repeats in complete genomes. Bioinformatics 15:426-427.

Lindley, J. 1833. Petunia violacea. Bot. Register 6:1626.

Loudon, J.W. 1840. Ladies flower garden of ornamental annuals. Loudon, London.

Promega. 2004. pGem-Teasy vector systems. 9 Sept. 2004. <http://www. promega.com/tbs/tm042/tm042.pdf $>$.

Mayol, M. and J.A. Rossello. 2001. Why nuclear ribosomal spacers (ITS) tell different stories in Quercus. Mol. Phylogenet. Evol. 19:167-176.

Niesbach-Klösgen, U., E. Barzen, J. Bernhardt, W. Rohde, Z. SchwarzSommer, H. Reif, U. Wienand, and H. Saedler. 1987. Chalcone synthase genes in plants: A tool to study evolutionary relationships. J. Mol. Evol. 26:213-225.

Qbiogene. 2004. Bio 101 protocol.9 Sept. 2004. <http://www.qbiogene. com/technical/protocols/dna-kits/pdf/rpm.pdf $>$.

Rauscher, M.D., R.E. Miller, and P. Tiffin. 1999. Patterns of evolutionary rate variation among genes of the anthocyanin biosynthetic pathway. Mol. Biol. Evol. 16:266-274.

Schinz, H. and H. Thellung. 1915. Petunia integrifolia (Hooker) Schinz et Thellung comb. nov. Vierteljahrsschrift Naturforschenden Gesellschaften Zurich 60:361.

Shepherd, A., S. Anderson, and S. Smith. 1990. Species-specific repeated DNA sequences from Petunia. Plant Sci. 67:57-62.

Smith, L.B. and R.M. Downs. 1964. Notes on Solanaceae. Phytology 10:439-441, 452- 453.

Smith, L.B. and R.M. Downs. 1966. Flora ilustrada Catarinense, Solanaceae. Herbario Barbosa Rodrigues, Conselho Nacional de Pesquisas Departamento de Recursos Naturals Renovaveis, Santa Catarina, Brazil. p. 266-271.

Tsukamoto, T., T. Ando, M. Kurata, H. Watanabe, H. Kokubun, G. Hashimoto, and E. Marchesi. 1998. Resurrection of Petunia occidentalis R.E. Fr. inferred from a cross-compatibility study. J. Jpn. Bot. 73:15-21.

Vilmorin, R. 1863. Petunia hybrida. Les fleurs de pleine terre, Chez Vilmorin-Andrieux, Paris. p. 615.

Wijsman, H.J.W. 1982. On the interrelationships of certain species of Petunia. I. Notes on the parental species of Petunia hybrida. Acta Bot. Neerlanden 31:477-490.

Wu, W., B.A. Schaal, C.Y. Hwang, Y.C. Chiang, and T.Y. Chiang. 2003. Molecular cloning and evolutionary analysis of Miscanthus alphatubulin genes. Amer. J. Bot. 90:1513-1521.

Xia, X. and Z. Xie. 2001. DAMBE: Data analysis in molecular biology and evolution. J. Hered. 92:371-373.

Zeboudj, F., A. Kabbaj, K. Alaoui, D. Peltier, A. Tagmount, CA. Raquin, M. Darmency, D. Maizonnier, H. Dulieu, and A. Bervillé. 1994. Variation of ribosomal DNA and inheritance of polymorphisms in six Petunia hybrida lines. Agronomie 14:485-495. 